\title{
Studying the Relationship between Company Size, Earnings Management in Initial Public Offerings of Stock and Performance of the Companies Listed on Tehran Stock Exchange
}

\author{
Mohsen Rahbar ${ }^{1} \&$ Davood Khodadady ${ }^{2}$ \\ ${ }^{1}$ Bandar Abbas Branch, Islamic Azad University, Bandar Abbas, Iran \\ ${ }^{2}$ Department of Accounting, Bandar Abbas Branch, Islamic Azad University, Bandar Abbas, Iran \\ Correspondence: Mohsen Rahbar, Bandar Abbas Branch, Islamic Azad University, Bandar Abbas, Iran
}

Received: June 21, 2015 Accepted: July 20, 2015 Online Published: August 18, 2015

doi:10.5539/ass.v11n24p293 URL: http://dx.doi.org/10.5539/ass.v11n24p293

\begin{abstract}
The aim of the present study is to explore the relationship between company size, earnings management in initial public offerings of stock and performance of companies listed on Tehran Stock Exchange during the time period of 2003 - 2012. In this study company size has been considered as an independent variable in order to explore and study its effect on earnings management and stock performance of companies in initial public offerings. In this study, in which panel data with fixed effects were used, results obtained from analyzing companies' data by using multivariate regression tests at $95 \%$ confidence level indicated that there is a reverse and significant relationship between company size and the extent of earnings management in initial public offerings (IPO). On the other hand, the results indicated that company size has a direct effect $(p<0.01)$ on the relationship between earnings management in initial public offerings (IPO) and short- and long-term performance of stock price of the company.
\end{abstract}

Keywords: company size, initial public offerings, short-term performance of stock price, long-term performance of stock price

\section{Introduction}

At present, technology advancement and wide circumferential changes have caused an increasing acceleration in economy and due to increasing competition among institution, obtaining the desired income also has been restricted and the context for bankruptcy occurrence also has increased. Today, investors are seeking to estimate the cash flow of the institute they have invested in so that they can judge their stock value (Mousavi et al., 2010). Also, for estimating their stock value they need some information regarding cash flow. Predicting cash flow requires a number of economic decisions, especially that of investment (Chahine \& Filatotchev, 2012). Among the studies conducted in the past, investment sensitivity to cash flow was studied (Hovakimian, 2010), however the mutual relationship between these two variables have never received any special attention from researchers. On the other hand, we cannot reject the significant effect of technology in terms of technology bubble in stock market on mutual relations of these two variables as well.

In advanced countries, public stock offerings and converting private ownership to that of public has been often welcomed so much due to its numerous advantages such as increased capital, more competition, tax exemptions, access to cheap financial resources, etc. In Iran, with regards to Article 44 of the constitution law and expansion of the range of privatization in our country, in recent years initial public offerings has received considerable attention and welcomed by companies. However, one of the issues that we are facing with in this area is stock valuation of initial public offerings (Hearn, 2011) that, due to its great importance, was studied in so many studies. Initial public offering, is the first public offering of the stock of a company that might have been active prior to the offering also but its activity has not been in the public range and therefore, due to information asymmetry, evaluation of its assets is based on insufficient and incomplete information. On the other hand, considering the fact that prices are dependent and subjected to multiple complex variables which are often intercorrelated, the issue of evaluation becomes more complex and problematic that in turn leads to occurrence of some abnormalities in initial public offerings (IPO) (Arab Mazar Yazdi, \& Ghasemi, 2009). Among the most important existing abnormalities in initial public offerings (IPO), Price drop in long-term, undervaluation and hot 
initial public offerings can be mentioned (Haghbin, 2008).

Financial reporting is considered as an important informational source for economic decision-makings that managers, investors, creditors and other users use them for solving their information needs. Since information is not made available to users equally, therefore, an information asymmetry is created between managers and investors (Hosseini \& Salar, 2012). Information asymmetry is a situation in which managers have more undisclosed information in comparison to investors regarding operational and other aspects of the company in future (Hasas Yeganeh et al., 2009). This causes managers to have the opportunity and motivation for earnings management. IPO companies misuse the lack of investors' attention to temporary nature of increased earnings due to accruals and trade stock for more than its actual value. Considering the fact that mangers have to return accruals in next periods, probability of reduced earnings of companies with weak performance in next periods increases. It is because for those companies with weak performance who get engage in earnings management, it is possible that the cash flows will not be sufficient for hiding the impact of returned accruals. Therefore, it is expected that detection of earnings management at the time of initial offering would cause external investors to reconsider Their perceptions of the quality of future earnings and modify their perceptions of these companies who engage in earnings management on the basis of accruals (Ebrahimi Kordlor, \& Hassani Azar Dariani, 2006). Considering the above discussions, the main problem of this study is to explore the relationship between company size, earnings management in stock's initial public offerings and performance of the companies listed on Tehran Stock Exchange that for this purpose in the following the research method is presents and next research findings and conclusion are presented.

\subsection{Research Hypotheses and Related Models}

$1^{\text {st }}$ hypothesis: there is a significant relationship between company size and the level of earnings management in initial public offerings (IPO).

Earnings management $\mathrm{i}_{\mathrm{t}, \mathrm{t}}=\beta_{0+} \beta_{1} \operatorname{Ln}\left(\right.$ size $_{\mathrm{i}, \mathrm{t}}+\beta_{2}$ Board Ownership $_{\mathrm{i}, \mathrm{t}}+\beta_{3}$ Auditor reputation $_{\mathrm{i}, \mathrm{t}}+\beta_{4}$ EPS $_{\mathrm{i}, \mathrm{t}}+\beta_{5}$ Debt-ratio $\mathrm{i}_{\mathrm{i}, \mathrm{t}}+\beta_{6}$ Loss-dummy $_{\mathrm{i}, \mathrm{t}}+\beta_{7}$ Current Asset $_{\mathrm{i}, \mathrm{t}}+\beta_{8}$ Age $_{\mathrm{i}, \mathrm{t}}+\varepsilon_{\mathrm{i}, \mathrm{t}}$

$2^{\text {nd }}$ hypothesis: company size has an effect on the extent to which earnings monument level in initial public offerings (IPO) affects short-term performance of stock price of a company.

$$
\begin{aligned}
\operatorname{CAR}(0,5)_{\mathrm{i}, \mathrm{t}}= & \beta_{0}+\beta_{1} \text { Earnings management }_{\mathrm{i}, \mathrm{t}}+\beta_{2} \mathrm{Ln}\left(\mathrm{size}_{\mathrm{i}, \mathrm{t}}+\beta_{3} \text { Board Ownership }_{\mathrm{i}, \mathrm{t}}+\beta_{4} \text { Auditor reputation }_{\mathrm{i}, \mathrm{t}}\right. \\
& +\beta_{5} \mathrm{EPS}_{\mathrm{i}, \mathrm{t}}+\varepsilon_{\mathrm{i}, \mathrm{t}}
\end{aligned}
$$

$3^{\text {rd }}$ hypothesis: company size has a effect on the extent to which earnings managements in initial public offerings (IPO) affects long-term performance of the stock price of a company .

$$
\begin{aligned}
\operatorname{CAR}(0,24)_{i, \mathrm{t}}= & \beta_{0}+\beta_{1} \text { Earnings management } \mathrm{i}_{\mathrm{i}, \mathrm{t}} \\
& \beta_{2} \operatorname{Ln}\left(\text { size }_{\mathrm{i}, \mathrm{t}}+\beta_{3} \text { Board Ownership }_{\mathrm{i}, \mathrm{t}}+\beta_{4} \text { Auditor reputation }_{\mathrm{i}, \mathrm{t}}\right. \\
& +\beta_{5} \operatorname{EPS}_{\mathrm{i}, \mathrm{t}}+\varepsilon_{\mathrm{i}, \mathrm{t}}
\end{aligned}
$$

\section{Definition of the Variables}

Earnings management (Earning Management $t_{i, t}$ ): The extent of earnings management in initial public offerings that has been calculated through Discretionary accruals with the use of Dechow et al., (1995) method which known as "modified model of Jones" and is presented as the following:

$$
-T A=N I-C F O
$$

Where, TA is total accruals, CFO is cash obtained from operations and NI is net profit. Then, the following model of total accruals against change in sales and also final cost of the period's fixed assets has been fitted:

$$
-T A_{i t}=\alpha \frac{1}{A_{i t-1}}+\beta \frac{\Delta R E V_{i t}}{A_{i t-1}}+\gamma \frac{P P E_{i t}}{A_{i t-1}}+\varepsilon_{i t}
$$

Where, $T A_{i t}$, is total accruals in year $\mathrm{t}$ for $\mathrm{i}$ company, $\triangle R E V_{i t}$ is total incomes of the year $\mathrm{t}$ minus the total incomes of the previous year for the company i, $P P E_{i t}$ is the ammounf of gross fixed assets in year $\mathrm{t}, A_{i t-1}$ is total assets at the end of the previous years for the company i, $\alpha, \beta$ and $\gamma$ coefficients are the coefficients of Jones' model and $\varepsilon_{i t}$ is the model's error in the year $\mathrm{t}$ for company $\mathrm{i}$.

Non-discretionary accruals (NDAC) is also calculated from the following relationship:

$$
-N D A C_{i t}=\alpha \frac{1}{A_{i t-1}}+\beta \frac{\Delta R E V_{i t}-\triangle R E C_{i t}}{A_{i t-1}}+\gamma \frac{P P E_{i t}}{A_{i t-1}}+\varepsilon_{i t}
$$

Where, $\triangle R E C_{i t}$ is receivables for the year $\mathrm{t}$ minus receivables for the year $\mathrm{t}-1$ for company $\mathrm{i}$ and, $\alpha, \beta$ and 
$\gamma$ coefficents are also cacualted throught least sqarue roots method in the following model. Discretionary accruals (DAC) also are calculated with the use of the following model:

$$
\text { - } D A C_{i t}=T A C_{i t}-N D A C_{i t}
$$

Cumulative abnormal short-term return $\left(\operatorname{CAR}(0,5)_{i, t}\right)$ : In order to calculate this variable, abnormal cumulative return of 5 days after the date of initial public offering was calculated.

Cumulative abnormal long-term return $\left(\operatorname{CAR}(0,5)_{i, t}\right)$ : In order to calculate this variable, abnormal cumulative return from the date of stock's initial public offering to 24 months after the data of initial public offering has been calculated.

Company size ( $\left.\operatorname{Ln}(\text { Size })_{i, t}\right)$ : Which is equal to natural logarithm of total sum of assets.

Earnings management (Earning Management $t_{i, t}$ ): Extent of earnings management in initial public offerings that in this study has been calculated from Discretionary accruals with the use of Dechow et al. (1995) method which is known as "modified model of Jones".

Ownership percentage of board of directors members (Board Ownership ${ }_{i, t}$ ): It is calculated as the percentage of stock ownership of board of directors to total stock of a company.

Auditor reputation (Auditor reputation ${ }_{i, t}$ ): It is a dummy variable, if audit organization is the company's auditor a value of 1 will be allocated to this variable and otherwise, a value of 0 will be allocated to it.

Earnings per share $\left(E P S_{i, t}\right)$ : Earnings per share which is obtained from the ratio of net earnings to the number of stocks of a company.

Ratio of long-term debt to total sum of assets (Debt Ratio ${ }_{i, t}$ ): It is calculated From dividing long-term debts of a company to total sum of its assets.

Loss in the previous financial year of the initial public offering (Loss Dummy ${ }_{i, t}$ ): It is a dummy variable, that if the company has been in loss in the financial year before initial public offering a value of 1 is allocated to it and otherwise, a value of 0 will be allocated.

Ratio of current assets to total assets (Current Asset ${ }_{i, t}$ ): Is calculated by dividing current assets to total assets.

Company age $\left(\operatorname{Age}_{i, t}\right)$ : Refers to the difference in establishment date of the company and the date of its initial public offering.

\section{Research Method}

Research method of the present study in terms of nature and content is of correlation type which is analyzing the correlation relationship by using secondary extracted data from financial statements of companies listed on Tehran Stock Exchange. This study was conducted in an inductive - deductive reasoning framework. The reason of using a correlation method is to detect correlation relations between variables. Correlation study is one the sub-types of descriptive research. In the present study first the correlation between research variables has been tests and in case of existence of correlation among the research variables, multiple -regression models have been estimated. On the other hand, the present study is an Ex-Post Facto study (semi-experimental). It means that it is conducted on the basis of past and historical data analysis (financial statements of companies). Also, this study is a bibliographical and analytical - causative study and is also based on panel data analysis. Therefore, the present research in terms of aim and objective is an applied study and in terms of method is a descriptive - correlation study.

\subsection{Research Population and Sample}

The actual required data of this article were collected from actual data of companies listed in Tehran Stock Exchange that during the time span from march 20, 2002 to 19 march 2013, for the first time have engaged in public offering their stock, on the condition that:

1. They are not among Investment firms and financial intermediaries;

2. Their fiscal year ends on 19 th march every year.

The sectors of industry studied in this research include automotive and parts manufacturing, medicine, manifesting of metal products, manufacturing of Other non-metallic mineral products, cement, Lime, gypsum, petroleum coke products and nuclear fuel, basic metals, sugar, ceramic and tile, rubber and plastics, equipment and machinery, chemical products, food products and beverages except sugar, textiles, etc . 


\subsection{Data Collection Method and Tools}

In this study, for the purpose of collecting the required data for calculation of variables, "Rah Avard Novin" and "Tadbir Pardaz" databases have been used. In those cases in which the existing data in these databases have been incomplete, the manual archives available in the library of Stock Exchange Organization and internet site of research, development of Islamic Studies of Stock Exchange Organization (Note 1) have been used. In general, in this article the bibliographical method has been used for data collection. In this way that for preparing literature review and theoretical principles of the research the available documents and theses in libraries as well as available articles on websites have been used.

\section{Data Analysis and Results}

Table 1 indicates the descriptive statistics of the research variables during the time span of this study. Descriptive statistics of research variables that have been measured with the use of companies data during the time span of this study (2002 to 2013) include average, mean, standard deviation, minimum and maximum.

Table 1. Descriptive statistics of research variables

\begin{tabular}{|c|c|c|c|c|c|c|}
\hline \multicolumn{2}{|c|}{ Variables description } & \multirow{2}{*}{$\begin{array}{c}\text { Average } \\
0.2866\end{array}$} & \multirow{2}{*}{$\begin{array}{c}\text { Mean } \\
0.2946\end{array}$} & \multirow{2}{*}{$\begin{array}{c}\begin{array}{c}\text { Standard } \\
\text { deviation }\end{array} \\
0.1028\end{array}$} & \multirow{2}{*}{$\begin{array}{c}\text { Min. } \\
0.1053\end{array}$} & \multirow{2}{*}{$\begin{array}{c}\text { Max. } \\
0.4813\end{array}$} \\
\hline $\begin{array}{c}\text { Cumulated short-term abnormal } \\
\text { return }\end{array}$ & CAR & & & & & \\
\hline Earnings management & Earnings management & 0.1396 & 0.1430 & 0.1021 & -0.0233 & 0.2867 \\
\hline $\begin{array}{l}\text { Ownership percentage of the } \\
\text { members of board of directors }\end{array}$ & Board Ownership & 0.4722 & 0.4839 & 0.2172 & 0.1295 & 0.7834 \\
\hline Auditor reputation & Auditor reputation & 0.2182 & 0.0000 & 0.4168 & 0.0000 & 1.0000 \\
\hline $\begin{array}{l}\text { Long-term debt ratio to total sum } \\
\text { of assets }\end{array}$ & Debt ratio & 0.1367 & 0.0950 & 0.1606 & 0.0000 & 0.7556 \\
\hline Dummy variable of loss & Loss dummy & 0.2182 & 0.0000 & 0.4168 & 0.0000 & 1.0000 \\
\hline $\begin{array}{l}\text { Ratio of current assets to total } \\
\text { assets }\end{array}$ & Current Asset & 0.5711 & 0.5243 & 0.2413 & 0.0986 & 0.9949 \\
\hline Company age (year) & Age & 17.1000 & 18.0000 & 6.1001 & 7.0000 & 28.0000 \\
\hline Company size & Ln (size) & 11.7080 & 11.7770 & 0.8770 & 10.2018 & 13.8447 \\
\hline
\end{tabular}

In the following for testing reliability, Im, Pesaran, Shin (1997) and Levin \& Lin (1992) tests were used, the results of which are presented in Table 2 and 3.

Table 2. Im, Pesaran, Shin test (IPS)

\begin{tabular}{cccccccccc}
\hline Variable & CAR & $\begin{array}{c}\text { Earnings } \\
\text { management }\end{array}$ & $\begin{array}{c}\text { Board } \\
\text { Ownership }\end{array}$ & $\begin{array}{c}\text { Auditor } \\
\text { reputation }\end{array}$ & $\begin{array}{c}\text { Debt } \\
\text { ratio }\end{array}$ & $\begin{array}{c}\text { Loss } \\
\text { dummy }\end{array}$ & $\begin{array}{c}\text { Current } \\
\text { Asset }\end{array}$ & Age & Ln(size) \\
\hline W-stat & -25.2296 & -3.09465 & -3.37952 & -19.4322 & -18.8967 & 17.7146 & -27.0077 & 34.8471 & -63.1932 \\
p-value & .0000 & 0.0010 & 0.0004 & .0000 & .0000 & 0.0001 & .000 & 0.0003 & 0.0072 \\
\hline
\end{tabular}

Table 3. Levin and Lin test (LL)

\begin{tabular}{cccccccccc}
\hline Variable & CAR & $\begin{array}{c}\text { Earnings } \\
\text { management }\end{array}$ & $\begin{array}{c}\text { Board } \\
\text { Ownership }\end{array}$ & $\begin{array}{c}\text { Auditor } \\
\text { reputation }\end{array}$ & Debt ratio & $\begin{array}{c}\text { Loss } \\
\text { dummy }\end{array}$ & $\begin{array}{c}\text { Current } \\
\text { Asset }\end{array}$ & Age & Ln(size) \\
\hline T-stat & $11.5684-$ & $3.9119-$ & $12.4227-$ & -19.1026 & $13.0826-$ & $16.026-$ & $19.308-$ & 9.28544 & $26.2495-$ \\
p-value & .000 & .0000 & 0.0169 & .0000 & 0.0010 & 0.0016 & 0.0018 & 1.0000 & .0000 \\
\hline
\end{tabular}

Considering the results of IPS test (Table 3), since the value of $\mathrm{p}$ is smaller than 0.05 for all the variables, therefore, these research variables during the study period are at a reliable level. Considering the results of LL test (Table 2), since p-value is smaller than 0.05 , all variables are reliable during the study period. Therefore, results of IPS and LL tests indicate that the average and variance of the variables were fixed throughout the time and the variables' covariance is as well fixed in different years. Therefore, using these variables in the model will not create Spurious regression. 
Also, considering the existing research literate and also the nature of research hypotheses in this article panel data have been used. For determining the proper model (panel with fixed or random effect) for testing hypotheses Chaw and Hausman tests have been used, the results of which are presented in Table 4 and 5:

Table 4. Chaw test

\begin{tabular}{llll}
\hline Regression model & f-value & Probability & Result \\
\hline $\mathbf{1}^{\text {st }}$ model & $264.621^{* *}$ & .0000 & Rejection of null hypothesis - panel model \\
$\mathbf{2}^{\text {nd }}$ model & 1.076 & 0.345 & Conformation of null hypothesis - pooled model \\
$\mathbf{3}^{\text {rd }}$ model & 19.183 & 0.0031 & Rejection of null hypothesis - panel model \\
\hline
\end{tabular}

Regarding the $1^{\text {st }}$ and $3^{\text {rd }}$ models, considering the significance level, results of Chaw test indicate that null hypothesis (pooled model) is not confirmed. In other words, there are Individual or group effects that panel data should be used for research regression model estimation that in the following section for determining the type of panel data model (with fixed or random effects) Huasman test was used. However, regarding the second model, results of Chaw test indicate that null hypothesis (pooled model) is confirmed. In other words, there are no individual or group effects present and therefore pooled data method should be used for research regression model estimation, hence, there is no need to perform Hausman test.

After specifying that intercept is not the same for different years, the method used in model estimation (fixed or random effects) should be determined. Therefore, Hausman test was used. Huasman test tests null hypothesis indicating to Consistency of estimates of random effects against its opposite hypothesis indicating to inconsistency of estimates of random effects.

Table 5. Hausman test

\begin{tabular}{cccc}
\hline Regression model & $\chi^{2}$ value & Probability & Test result \\
\hline $\mathbf{1}^{\text {st }}$ model & $156.071^{* *}$ & 0.0008 & Rejection of null hypothesis - panel model with fixed effects \\
$\mathbf{3}^{\text {rd }}$ model & $69.321^{* *}$ & 0.0039 & Rejection of null hypothesis - panel model with fixed effects \\
\hline$* *<05$ & & &
\end{tabular}

Resultss related to Hausman test for 1st and 3d models have been respectively shown in table 4. Results indicate

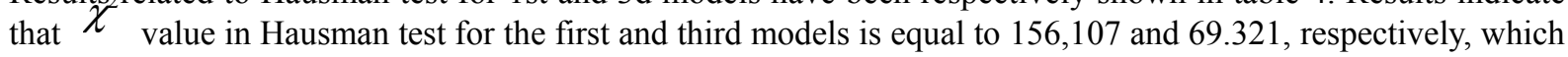
is significant at $99 \%$ confidence level which in turn indicates that the opposite hypothesis is confirmed. Hence, considering Hausman test fitting first and third regression models of this study would be appropriate with the use of panel data model with fixed effects. In the following, research hypotheses are tested:

H1: There is a significant relationship between company size and the extent of earnings management in initial public offerings (IPO).

After testing regression assumptions and assuring that these assumptions are met, results obtained from the above regression equation fit for manufacturing companies are presented in Table 6. F-value (11.276) also indicate that the whole regression model is significant. Coefficient of determination and adjusted coefficient of determination of the above model are $652 \%$ and $50.7 \%$, respectively. Therefore, it can be concluded that in the mentioned regression equation, only about $50.7 \%$ of the changes in earnings management of companies under study are explained by independent and control variables.

As per table 6, significance level of the variable of company size $(\operatorname{Ln}($ size $))$ is equal to 0.043 , which is smaller than the specified significance level in this study (5\%); also absolute value of t-value related to this variable (2.588) is larger than the obtained t-value from the table with the same freedom degree. Therefore, at $95 \%$ confidence level, the obtained coefficient for the above variable in the above mentioned regression model is significant and hence, $1^{\text {st }}$ hypothesis indicating that there is a significant relationship between company size and extent of earnings management in initial public offerings (IPO) is confirmed.

$\mathrm{H} 2$ : Company size has an effect on the relationship between earnings management in initial public offerings (IPO) and long -term performance of stock price of the company 
Table 6. Results obtained from regression equation fit

\begin{tabular}{ccccc}
\hline Variable name & $\begin{array}{c}\text { Coefficient of } \\
\text { the variable }\end{array}$ & Coefficient value & t-value & Sig. level \\
\hline Constant value & $\beta 0$ & $1 / 522$ & 2.873 & 0.004 \\
Ln(size) & $\beta 1$ & -0.843 & -2.588 & 0.043 \\
Board Ownership & $\beta 2$ & 1.211 & 3.158 & 0.018 \\
Auditor reputation & $\beta 3$ & -0.677 & -3.838 & -2.987 \\
EPS & $\beta 4$ & -0.911 & 2.847 & 0.001 \\
Debt ratio & $\beta 5$ & 1.241 & 5.073 & 0.026 \\
Loss dummy & $\beta 6$ & 0.865 & -2.847 & 0.000 \\
Current Asset & $\beta 7$ & -0.441 & -2.632 & 0.023 \\
Age & $\beta 8$ & -1.301 & & 0.037 \\
Coefficient of determination & 0.562 & significance of(P-Value) & 11.276 \\
Adjusted Coefficient of & 0.507 & Durbin - Watson value & .000 \\
determination & & & & 1.925 \\
\hline
\end{tabular}

After testing regression assumptions and assuring that they are met, results obtained from the above regression equation fit for manufacturing firms have been presented in Table 7. F-value is equal to 17.672 which indicates that total regression model is significant. Coefficient of determination and adjusted coefficient of determination of the above model are equal to $72.6 \%$ and $69.8 \%$, respectively. Therefore, it can be concluded that in the mentioned regression equation, only about $69.8 \%$ of the changes in long-term performance of the companies under study are explained by independent and control variables. Significance level of the variable of interactive effect of earnings management and company size (0.029) is smaller than significance level considered in the present study (5\%); also absolute value of t-value related to this variable (2.987) is larger than the obtained $\mathrm{t}$-value from the table with the same freedom degree. Therefore, $\mathrm{H} 0$ hypothesis is rejected at confidence level of 95\% and $\mathrm{H} 1$ hypothesis indicating that interactive effect of earnings management and company size is significant is confirmed, Therefore, $2^{\text {nd }}$ hypothesis indicating that company size has an effect on the relationship between earnings management in initial public offerings (IPO) and long -term performance of stock price of the company is confirmed.

Table 7. Results obtained from regression model fit

\begin{tabular}{ccccc}
\hline Variable name & Variable's coefficient & Coefficient value & t-value & Sig. level \\
\hline Constant value & $\beta 0$ & 0.961 & 3.091 & 0.006 \\
Earnings management & $\beta 1$ & -0.736 & -3.067 & 0.011 \\
Earnings management i,t $\times$ Ln(size) i,t & $\beta 2$ & 0.298 & 2.298 & 0.029 \\
Board Ownership & $\beta 3$ & -0.818 & -2.458 & 0.044 \\
Auditor reputation & $\beta 4$ & 1.067 & 2.847 & 0.014 \\
EPS & $\beta 5$ & 1.641 & 2.873 & 0.004 \\
Coefficient of determination & 0.726 & fignificance of(P-Value) & 17.672 \\
Adjusted Coefficient of determination & 0.698 & Durbin - Watson value & \multicolumn{1}{c}{1.781} \\
\hline
\end{tabular}

H3: Company size is effective on the relationship between earnings management in initial public offerings (IPO) and short-term performance of stock price of the company.

Results obtained from the above regression equation fit for manufacturing firms were presented in table 8 . Value of f-value (27.746) also indicate that the total regression model is significant. As it has been shown in the lower section of table 8 , coefficient of determination and adjusted coefficient of determination of the above model are respectively equal to $75.7 \%$ and $72.8 \%$. Therefore, it can be concluded that, in the mentioned regression equation, only $72.8 \%$ of the changes in short-term performance of companies under study are explained by independent and control variables. In this table, positive (negative) values in the column related to coefficient value indicate to the direct (reverse) effect of each of the variables on short-term performance of companies under study.

As it is evident from Table 8 , the significance level of the interactive variable of earnings management and company size (0.0082) is smaller than the considered significance level in this study (5\%); also absolute t-value related to this variables (3.838) is larger than the obtained t-value from the table with the same freedom degree. Therefore, $\mathrm{H}_{0}$ hypothesis at $95 \%$ confidence level is rejected and $\mathrm{H}_{1}$ hypothesis indicating that the interactive 
effect of earnings management and company size is significant is confirmed. Hence, $3^{\text {rd }}$ hypothesis indicating that company size is effective on the relationship between earnings management in initial public offerings (IPO) and short-term performance of company's stock price is conformed.

Table 8. Results obtained from regression equation fit

\begin{tabular}{ccccc}
\hline Variable name & Variable's coefficient & Coefficient value & t-value & Sig. level \\
\hline Constant value & $\beta 0$ & 3.641 & 2.873 & 0.004 \\
Earnings management & $\beta 1$ & -1.209 & -5.073 & 0.0001 \\
Earnings management i,t $\times \operatorname{Ln}($ size $)$ & $\beta 2$ & 0.567 & 3.838 & 0.0082 \\
i,t & $\beta 3$ & -1.098 & -2.388 & 0.002 \\
Board Ownership & $\beta 4$ & 0.615 & -2.141 & 0.003 \\
Auditor reputation & $\beta 5$ & 1.311 & 2.601 & 0.0037 \\
EPS & 0.757 & f-value & 27.746 \\
Coefficient of determination & 0.728 & significance of(P-Value) & 0.000 \\
Adjusted Coefficient of & Durbin - Watson value & 2.231 \\
determination & &
\end{tabular}

\section{Conclusion and Recommendations}

Regarding the performance of small and medium sized companies which have been emerged newly in business field which are accompanied by special complexities, no accepted measurement criteria have been established so far (Aminul et al., 2010), while various financial indicators were used for evaluating the performance of small companies such as sales volume, profitability level, number of employees and customers and increased market share (Yadollahi et al., 2009; Nikbakht et al., 2010).

For data collection, there are some special operational limitations with regards to these traditional criteria that among them we can mention confidentiality of financial information and lack of interest of small businesses' owners to disclose such information. In addition, any kind of data related to profitability level also should be handled and used with caution, because this kind of information can be affected by some accounting actions such as minimization of income tax of entrepreneurs (Dechow et al., 1995). This is more clear in small businesses in which sales and assets indicators show a growth in the first years of their activities which is accompanied by a high level of error. Considering these reasons and also based on multiple other evidences, it can be said that the use of subjective criteria for measuring performance in studies related to small and medium sized businesses are developing and becoming popular (Jain, 2007; Nonahal Nahr et al., 2013).

The ability of a small company for growth and development depends on the performance of its key managerial activities. These activities can be divided into financial management, marketing, human resources and operational areas (Kotey \& Meredith, 1997) and it can be said that there are various factors that can be related to the performance of companies. The present study sought to study the relationship between company size, earnings management in initial public offerings of stock and performance of companies listed on Tehran Stock Exchange. Results of this study indicate that there is a reverse and significant relationship between company size and the extent of earnings management in initial public offerings. On the other hand, results indicate that company size has a direct effect on earning management in initial public offerings and short- and long-term performance of company's stock price. Based on the obtained results of this study a number of recommendations are presented below:

1. Legislative bodies including Stock Exchange Organization, Iran's Association of Investment Institutions, Brokers' Association, brokers and investment companies, all the activists in capital market and ... are recommended to pay more attention to relationships between company size and extent of earnings management in stock's initial public offerings which has been shown in the present study.

2. Activists in the capital market, decision makers, financial analysts and potential and actual investors in Stock Exchange in their analysis of investment projects in financial assets and securities are recommended to pay special attention to the relationships between company size and extent of earnings management in initial public offerings of stock. Also, the effect of company size on the relationship between earnings management and short-term and long-term performance of a company's stock price which has been shown in this study should be emphasized because consideration of these important factors leads to optimized selection of investment portfolio with minimum risk and maximum return. Finally, it increases the transparency of decision making environment and the obtained results. 


\section{References}

Aminul, I., Ruhani, A., \& Zamri, A. (2010). An Empirical Investigation of the Under-pricing of IPOs in the Chittagong Stock Exchange. International Journal of Economies and Finance, 2(4), 56-70.

Arab Mazar Yazdi, M., \& Ghasemi, M. (2009). Pricing of initial public offerings: Combination of Artificial neural networks and genetic algorithms. Accounting and Auditing Studies, 16(58), 12-25.

Chahine, S., \& Filatotchev, I. (2012). The effects of corporate governance and audit and non-audit fees on IPO Value. The British Accounting Review, 43.

Dechow, P., Sloan, R., \& Sweeney, A. (1995). Detecting earnings management. The Accounting Review, 70, 193-225.

Ebrahimi Kordlor, A., \& Hassani Azar Dariyani, E. (2006). Studying earnings managment at the time of initial public offering of stock in companies listed on Tehran Stock Exchange. Accounting \& Auditing Studies, 45.

Haghbin, Z. (2008). Studying different type of abnormality related to initial public offerings of stock in Tehran Stock Exchange (Master's thesis). Al-Zahra University, Iran.

Hassas Yeganeh, Y., Raeesi, Z., \& Hosseini, S. M. (2009). The relationship between corporate governance and performance of companies listed on Tehran Stock Exchange. Iran's J. of Management Sci., 4(13), 75-100.

Hearn, B. (2011). The impact of corporate governance measures on the performance of West African IPO firms. Emerging Market Review, 130. http://dx.doi.org/10.1016/j.ememar.2011.02.004

Hosseini, S. M., \& Salar, J. (2012). Studying the effect of market-orientation and innovation on performance of food companies listed on Stock Exchange. New Marketing Studies, 2(3), 107-119.

Hovakimian, A. (2010). In search of conclusive evidence: How to test for adjustment to target capital structure. Journal of Corporate Finance, 17, 33-44. http://dx.doi.org/10.1016/j.jcorpfin.2010.07.004

Jain, B. A. (2007). Test of Adverse Selection Models in the New Issues Market. Elsevier Information Learning Company, 25(3), 98-112.

Kotey, B., \& Meredith, G. G. (1997), Relationship among Owner/Manager Personal Values, Business Strategies, and Enterprise Performance. Journal of Small Business Management, 35(2), 37-61.

Mousavi, Z., Moridipur, H., \& Jari, A. (2010). Evaluating the effect of regulatory mechanisms of corporate governance on the performance of the companies listed on Tehran Stock Exchange. Financial Accounting, 2(6), 141-155.

Nikbakht, M. R., Seyedi, S. A., \& Hashm Al-hosseini, R. (2010). Studying the effect of board of directors characteristics on firm's performance. Accounting Advances (Social Sciences and Humanities of Shiraz), 12(3), 251-270.

Nonahal Nahr, A. A., Ali Nejad Sarokalaei, M., \& Khezri, P. (2013). Evaluating the effect of audit quality on earnings management in companies who have been recently listed on Tehran Stock Exchange. Accounting and Auditing Management Knowledge, 2(7), 103-114.

Yadollahi Farsi, J., Aghjani, H., \& Aghajani, A. A. (2009). Identification of effective internal factors on performance of small and medium sized companies and presenting an efficient and effective model. Researcher Management, 6(14), 12-28.

\section{Note}

Note 1. www.rdis.ir

\section{Copyrights}

Copyright for this article is retained by the author(s), with first publication rights granted to the journal.

This is an open-access article distributed under the terms and conditions of the Creative Commons Attribution license (http://creativecommons.org/licenses/by/3.0/). 